\title{
The Effect of Inflation, Exchange Rate, BI Rate and Dow Jones Index to Indonesia Composite Index in Indonesia Stock Exchange on the Year 2013-2018
}

\author{
Hasanudin \\ Universitas Nasional, Jakarta, Indonesia \\ Email: hasanudinsadikin910@gmail.com
}

\begin{abstract}
The purpose of this study is to demonstrate the influence of inflation, currency exchange rates, SBI interest rates, and the Dow Jones index on the Jakarta Composite Index on the Indonesian Stock Exchange from 2013 to 2018. Methods of quantitative research utilizing Structural Equation Modeling (SEM) analytic techniques in conjunction with the use of SmartPLS 3. The findings of this study indicate that inflation has a substantial negative influence on the CSPI. This indicates that as inflation increases, the $\mathrm{JCl}$ decreases. The exchange rate has a substantial negative effect on the $\mathrm{JCl}$. This demonstrates that the exchange rate variable has a direct effect on the direction of the high exchange rate, lowering the $\mathrm{JCl}$ in the process. The SBI interest rate has no effect on the $\mathrm{JCl}$ and is rather detrimental to it. This indicates that when the number of SBI interest rates increases, the CSPI remains same. The Dow Jones index has a sizable positive correlation with the CSPI. This indicates that the Dow Jones index's rise has an effect on the $\mathrm{JCl}$. By a factor of 0.982 , the Dow Jones Index has the greatest effect on work motivation, followed by inflation, exchange rates, and SBI interest rates on the IHSG on the 2013-2018 Stock Exchange.
\end{abstract}

Keywords: Inflation, Exchange Rate, BI Rate, Dow Jones Index, Indonesia Composite Index.

\section{A. INTRODUCTION}

The Dow Jones Composite Stock Price Index (JCI) is a broad measure of capital market activity. JCI enumerates a series of data points pertaining to the combined stock's price movements up to a specified date (Astuti, 2016). Typically, daily stock price changes are provided based on the stock exchange's closing price for that day. The index is provided for a specified time period. JCI Is a number that serves as a barometer of a joint stock's performance on the stock exchange (Taufiq \& Kefi, 2015). The objective of the combination is to account for the performance of multiple, if not all, shares listed on the stock exchange (Sunariyah, 2004).

An increase in the JCI indicates that the capital market is bullish; on the other hand, if it decreases, it means that the capital market is bearish. So, an investor must understand the pattern of stock price behavior in the capital market (Sari, 2019). The Composite Stock Price Index is one index that investors frequently monitor while investing on the Indonesia Stock Exchange. This is because this index is a weighted average of all stocks traded on the Indonesian Stock Exchange. As a result, an investor may determine if the market is pleased or sluggish by monitoring the Composite Stock Price Index movement (Ilmi, 2017). Diverse market situations 
necessitate distinct investment methods from investors. Numerous variables can influence the stock index, including changes in the benchmark interest rate, worldwide economic circumstances, global energy costs, and a country's political stability (Febriyanto, 2016). On April 1, 1983, the Composite Stock Price Index was created as a measure of the price movement of all shares listed on the Indonesia Stock Exchange, both ordinary and preferred stock. The Composite Stock Price (JCI) is a stock price index number that has been computed and collated to create a trend, where an index number is a numerical value that can be used to compare events in the form of periodic changes in stock prices (Jogiyanto, 2000).

The movement of the JCI is influenced by several factors, factors originating from within the country (internal) and factors arising from abroad (external) (Wijaya \& Agustin, 2015). Factors originating from within the country can come from fluctuations in currency exchange rates in a country against other countries, inflation rates, inflation rates, and interest rates in that country, economic growth, social, political, and security conditions. etc. While factors originating from abroad (external) are the stock exchanges that have a strong influence on the stock exchanges of other countries, namely stock exchanges belonging to developed countries such as America, Japan, England, and so on. In addition, investor behavior also affects the performance of the Jakarta Composite Index (Yanuar, 2012).

The inflation rate has an effect on the IDX's Composite Stock Price Index. Inflation is a term that refers to the depreciation of money's buying power. With inflation, the cost of products will continue to rise, eroding people's buying power (Kewal, 2012).

Based on data from Bank Indonesia, the following is inflation data that occurred in Indonesia from 2013 to 2018:

Table 1 Inflation Data in Indonesia
\begin{tabular}{|c|c|}
\hline Year & Inflation Rate (\%) \\
\hline 2013 & 8.38 \\
\hline 2014 & 8.36 \\
\hline 2015 & 3.35 \\
\hline 2016 & 3.02 \\
\hline 2017 & 3.61 \\
\hline 2018 & 3.13 \\
\hline
\end{tabular}

Source: Bank Indonesia Data

Table 1 shows that in 2013 the inflation rate was $8.38 \%$, caused by the increase in fuel prices, which increased the cost of food. In 2013, inflation hit 11.06 percent, the highest level since the 2008 financial crisis. And in 2014, the inflation rate only decreased by $0.02 \%$ from the previous year. In 2015 inflation experienced a drastic decline to $3.35 \%$. Inflation in 2015 was the lowest in the last five years since 2010; this was due to the weakening of people's purchasing power, resulting in a decrease in demand for goods so that traders did not increase prices. And in 2016, it was at 3.02; in 2017 , it was at $3.61 \%$, and in 2018 it was at $3.13 \%$. 
In 2013, inflation reached a record high of 11.06 percent, the highest level since the financial crisis of 2008 (Santi \& Hidayat, 2017).

The following are the SBI interest rates for 2013-2018, namely:

\begin{tabular}{|c|c|} 
Table 2 SBI Interest Rates \\
\hline Year & Interest Rate \\
\hline 2013 & 6.479 \\
\hline 2014 & 7.542 \\
\hline 2015 & 7.521 \\
\hline 2016 & 6 \\
\hline 2017 & 4.562 \\
\hline 2018 & 5.104 \\
\hline
\end{tabular}

Source: www.bi.go.id

Based on the data above, that throughout 2016, Bank Indonesia (BI) has slashed the benchmark interest rate, dubbed the BI Rate, four times in the last year. Since early 2016, the SBI interest rate has been lowered by 100 basis points (bps) to 6.5 percent. This position is the lowest since August 2013. The decline in the benchmark interest rate is aimed at spurring growth in the sluggish domestic economy.

The exchange rate of a foreign currency is the price of the currency of one country relative to the currencies of other countries (Thobarry, 2009). The rise of the rupiah against major currencies is a favorable development for investors.

The following is exchange rate data from 2013-2018, namely:

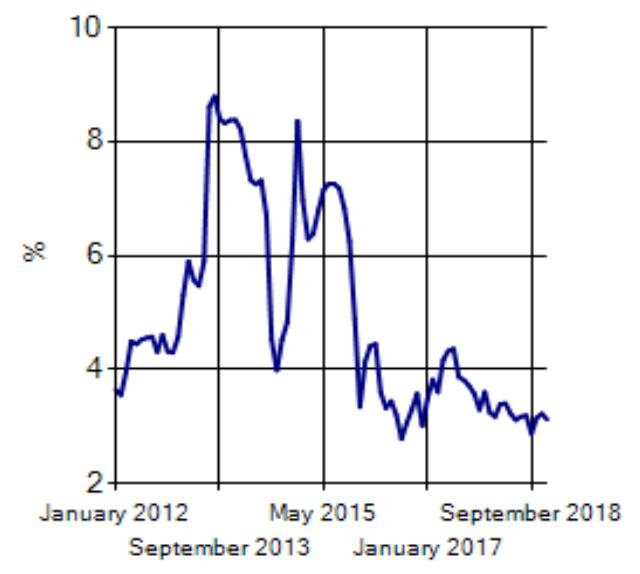

Figure 1 Exchange

Source: www.bi.go.id

Based on the graph above, it is clear that in early 2013 Indonesia's economic condition is targeted to grow by six percent, referring to last year's growth which was above this figure. However, beyond expectations, the weakening of the rupiah in 2013 the exchange rate on January $2=$ Rp. 9,733 per US dollar, then December $30=$ Rp. 12,331 per US dollar (-26.69\%) and December $31=$ Rp. 12,250 per US dollar ($25.89 \%)$. 
Apart from the Dow Jones Transportation Index, the Dow Jones Index is the oldest stock market index in America. The Wall Street Journal and Dow Jones \& Company editors jointly released the Dow Jones Index for the first time on May 26, 1896. The Dow Jones index is a weighted average of 12 companies from the United States' most essential industries (Kurniawan, 2013).

The following is the Dow Jones index data for 2013-2018 as follows:

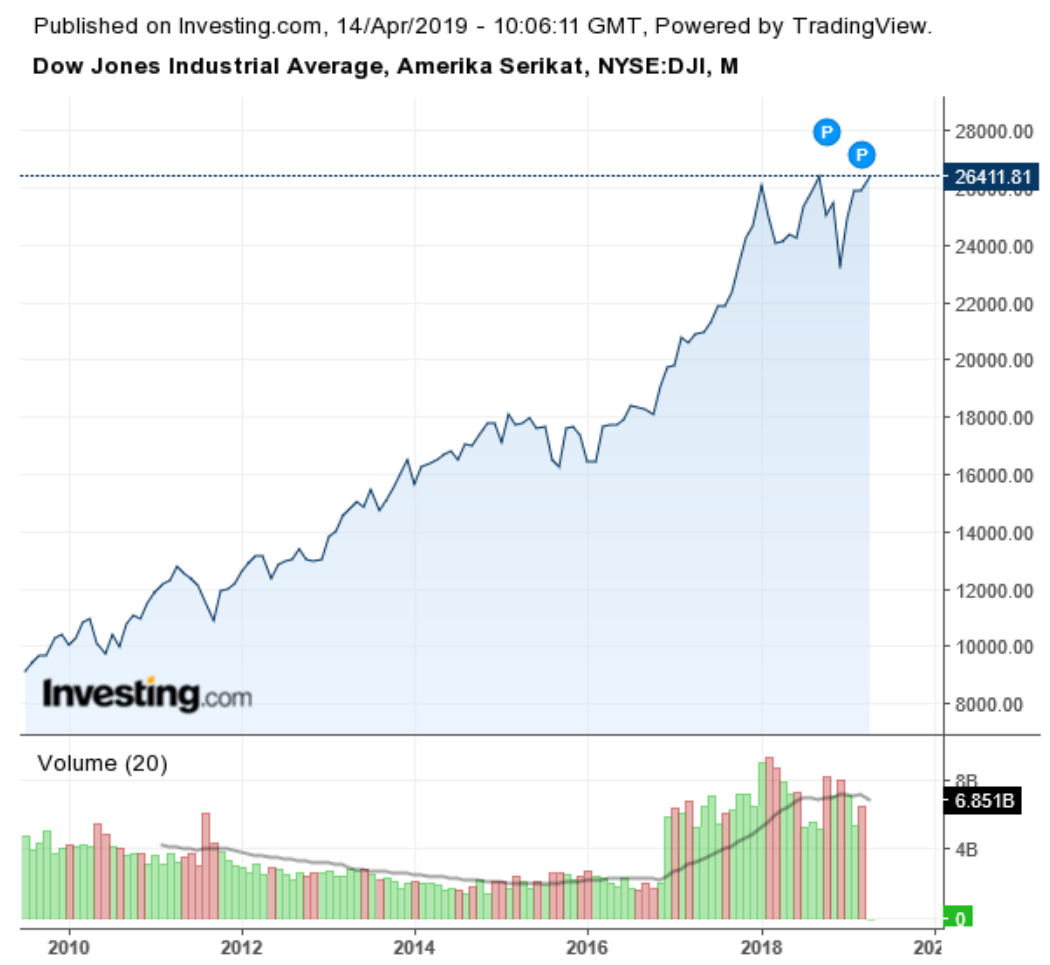

Figure 2 Graph of 2Dow Jones Industrial Average

The impact of external variables that affect the JCI, namely the influence of America (US), is tremendous for other countries; this also includes the power of companies and their investors. Thus, the DJIA (Dow Jones Industrial Average), which is one of the NYSE (New York Stock Exchange) indexes, will have an effect on the movement of other nations' indexes.

The framework of thinking in this study may be summarized as follows, based on the theoretical foundation and the findings of prior research:

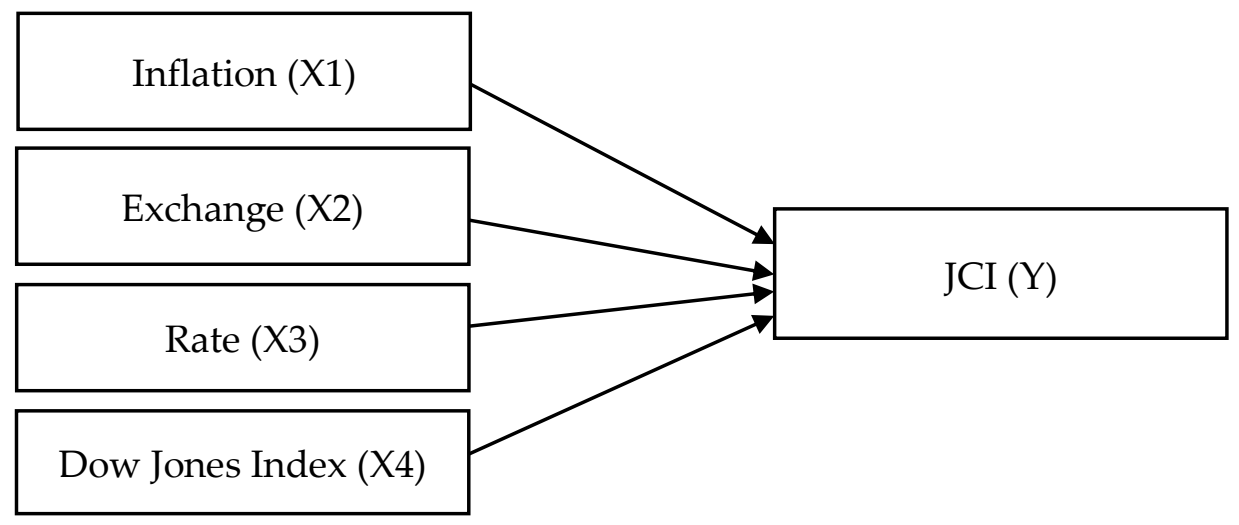


Based on the research framework, the hypotheses that can be formulated are as follows:

H1: Inflation affected the JCI on the IDX in 2013-2018

H2: Exchange rate affected the JCI on the IDX in 2013-2018

H3: Interest rates affected the JCI on the IDX in 2013-2018

H4: The Dow Jones Index acted as the JCI on the IDX in 2013-2018.

\section{B. METHOD}

The JCI index is constructed using all publicly traded firms as components in order to accurately reflect market conditions. The Indonesian Stock Exchange has the power to issue and/or omit from the JCI calculation one or more listed firms. The foundation for consideration is, among other things, the public's ownership of the listed company's shares (free float). Simultaneously, the market capitalization is fairly substantial. So that changes in the stock price of the listed companies can affect the fairness of the JCI movement. In this study, the JCI data used is the monthly IHSG Closing Price data published on the IDX in 2013-2018. According to Samsul (2006), the measuring tools used to determine the IHSG level are as follows:

Information:

$$
I H S G=\frac{N P}{N D} X 100 \%
$$

NP: The weighted average market value (number of shares listed on the stock exchange multiplied by the market price per share) of common shares and preferred shares on day $t$.

ND: Base value, which is the cumulative number of shares on the base day times the base price on the base day.

The independent variables are inflation $\left(X_{1}\right)$, exchange rates $\left(X_{2}\right)$, interest rates $\left(\mathrm{X}_{3}\right)$, and also the Dow Jones Index $\left(\mathrm{X}_{4}\right)$.

\section{Inflation $\left(\mathbf{X}_{1}\right)$}

According to Kuncoro (2013), the Consumer Price Index is used to monitor inflation (CPI). The CPI has historically been used to assess monetary policy's performance in containing inflation since it is more readily available than other measures such as the Free Trade Price Index (IHPB) and the GDP deflator. The CPI is a price index that is used to determine the general average change in the prices of a variety of commodities during a certain period of inflation. In this study, the inflation data used is the monthly closing price inflation data published in 2013-2018. The following formula describes the calculation of inflation:

$$
\text { Inflation }=\frac{I H K t-I H K t-1}{I H K t-1}
$$

\section{Exchange $\left(X_{2}\right)$}

According to Sukarno (2010:400), the real exchange rate is the relative price of goods between one country and another. Simply put, it can be analogized as follows, the price of a car in Indonesia is 300,000,000 rupiah, and the cost of a vehicle in America is $\$ 20,000$. To compare the costs of the two cars, we change them using the 
nominal exchange rate first; if 1 US dollar is 13,500, then the price of a vehicle in America is 30,000,000 rupiahs cheaper than in Indonesia. In this study, the exchange rate data used is the average monthly exchange rate data published in BI in 20132018. According to Sukirno (2010), to calculate the real exchange rate, the following formula can be used:

$$
\text { Real Exchange Rate }=\frac{\text { Exchange Rate X Domestic Goods Price }}{\text { Price of Overseas Goods }}
$$

\section{SBI Interest Rate $\left(X_{3}\right)$}

Indonesian Bank SBI certificates are short-term debt (1-3 months) securities issued by Bank Indonesia under a discount/interest scheme. SBI is one of the measures employed by Bank Indonesia to maintain the Rupiah's stability. Bank Indonesia can absorb surplus base money in circulation by selling SBIs.

A market mechanism based on an auction system determines the interest rate applied to each sale of SBI. Since early July 2005, BI has employed the "BI rate" mechanism (SBI interest rate), in which BI stated the target SBI interest rate for auctions for a specified time. This bid-ask spread is then utilized as a reference point for market players when they participate in the auction.

In this study, the SBI interest rate used is in the monthly period. Therefore, SBI interest rate data obtained in the daily period will be converted into monthly periods with the following formula:

Average SBI Interest Rate $=$ Total Daily Interest Rate for One Month Divided by the Number of Periods

Note: Bank Indonesia (BI) has stopped issuing Bank Indonesia Certificates (SBIs) with a tenor of fewer than nine months, as of February 2011.

\section{Dow Jones Index $\left(\mathrm{X}_{4}\right)$}

As defined by Tamara (2013), the Dow Jones Industrial Average (DJIA) is a price-weighted average of 30 stocks belonging to blue-chip firms that are typically leaders in their respective industries in the United States of America. These 30 stock markets concentrate on several sectors, especially automotive, steel, oil, and chemical (Hartman et al., 2001). In this study, the DJIA data used is the monthly DJIA Closing Price data published in 2013-2018. The Dow Jones index has the following calculation (Syarofi, 2014):

\section{Population and Sample}

$$
\text { DJIA }=\frac{\sum \frac{30}{i=1} p}{\text { DJIA Divisor }}
$$

A sample of data from the Indonesia Stock Currency at the end of each month was utilized in this study, including data on inflation, exchange rates, interest rates, and the Dow Jones index at the end of each month (close price). At the same time, the sample taken is the data for the period 2013-2018, which is calculated based on the average market value every month. 


\section{Data Collection Techniques}

Data is collected through online data available on the Indonesia Stock Exchange, which uses the JATS (JSX Trading System) system, which is transaction information between exchange members. Data from JATS may only be filled in by stock exchange members who are members of the Indonesian Clearing and Guarantee Corporation (KPEI) to avoid errors in the data input process. The data was taken from the official website of the Indonesia Stock Exchange (www.IDX.co.id) and the official website of Bank Indonesia (www.bi.go.id).

\section{Data Analysis Method}

The quantitative approach was used to analyze the data collected in this study, i.e., the use of numbers formulas or mathematical models to determine whether or not macroeconomic variables, in this case, the gross national product, SBI interest rates, inflation, and exchange rates, have an impact on the data collected in this study. The IHSG IDX incorporates foreign exchange and the Dow Jones index. PLS was utilized as a data analysis approach (Partial Least Square).

\section{RESULT AND DISCUSSION}

The results of data tabulation for the dependent and independent variables are presented in Appendix 1. The descriptive statistics of each variable are shown in Table 3 as follows:

Table 3 Descriptive Statistics

\begin{tabular}{|l|c|c|c|c|}
\hline \multicolumn{1}{|c|}{ Variables } & Minimum & Maximum & Mean & Std. Deviation \\
\hline Inflation & 2.790 & 8.790 & 5.051 & 1.865 \\
\hline Exchange & $9,686.65$ & $15,178.87$ & $12,773.88$ & $1,340.339$ \\
\hline SBI Interest Rate & 4.250 & 7.750 & 6.201 & 1.261 \\
\hline Dow Jones Index & $13,860.58$ & $26,458.31$ & $19,065.88$ & $3,478.374$ \\
\hline JCI & $4,195.090$ & $6,605.630$ & $5,227.085$ & 608.639 \\
\hline
\end{tabular}

Source: PLS Data Processing Results

Based on the descriptive statistical test results in Table 3, the results can be explained as follows.

1. During 2013-2018, the lowest inflation was at 2.79\% in August 2016, and the highest inflation was $8.79 \%$ in August 2013, with an average inflation rate of $5.051 \%$ and a standard deviation of $1.865 \%$. This means that inflation in 20132018 is centered at 5,051 with a standard deviation of $1.865 \%$.

2. During 2013-2018, the lowest exchange rate was IDR 9,686.65 in February 2013, and the highest exchange rate was IDR 15,178.87 in October 2018 with an average value of $12,773.88$ and a standard deviation of $1,340,339$. This means that the exchange rate for $2013-2018$ is concentrated at Rp. $12,773.88$ with a standard deviation of $1,340,339$.

3. During 2013-2018, the lowest SBI interest rate was $4.25 \%$ from September 2017 to April 2018, and the highest was 7.75\% from November 2014 to January 
2015 with an average inflation rate of $6.201 \%$ and a standard deviation of $1.261 \%$. This means that the SBI interest rate for 2013-2018 is centered at $6.201 \%$, with a standard deviation of $1.261 \%$.

4. During 2013-2018, the lowest Dow Jones Index was 13,860.58 in January 2013, and the highest was 26,458.31 in September 2018 with an average inflation rate of $19,065.88$ and a standard deviation of $3,478,374$. This means that the Dow Jones Index in 2013-2018 converges at 19,065.88 with a standard deviation of $3,478,374$.

5. During the 2013-2018 period, the lowest JCI was IDR 4,195,090 in August 2013, and the highest was IDR 6,605.630 in January 2018, with an average value of IDR $5,227,085$ and a standard deviation of 608,639 . This means that the exchange rate for 2013-2018 is concentrated at Rp. 5,227,085 with a standard deviation of 608,639 .

The results of data analysis using PLS are as follows:

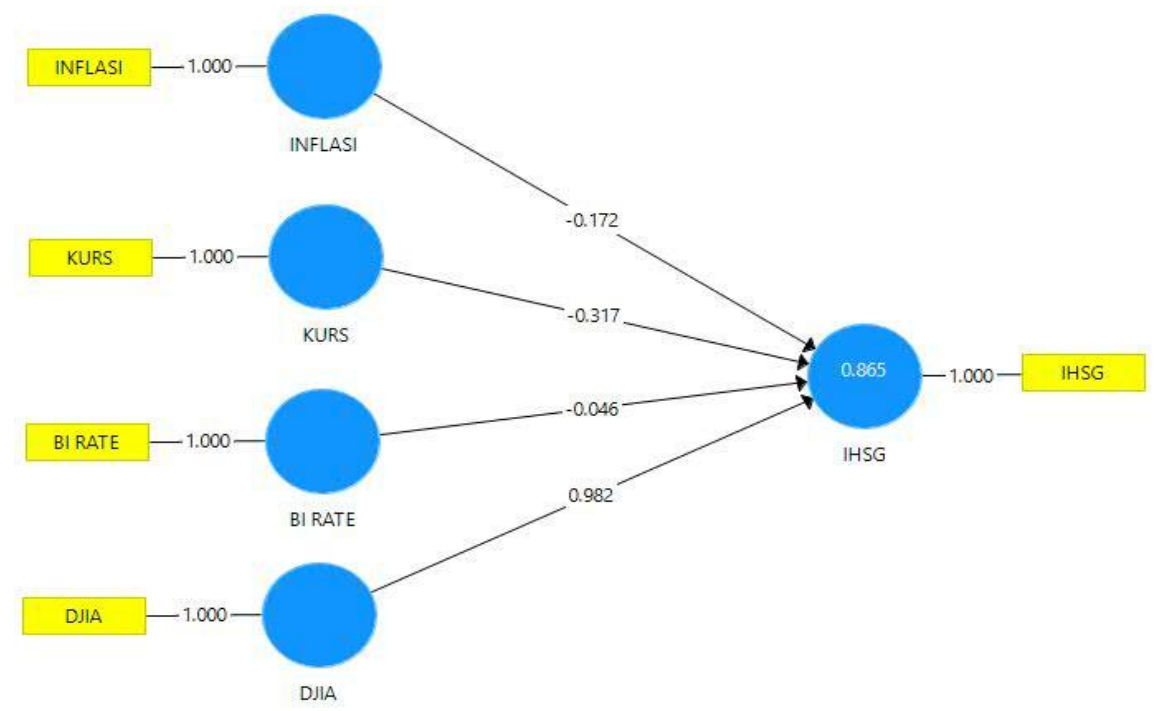

Figure 3 PLS Algorithm Output Results

In Figure 4.2 above, it is explained that the round shape is reflected as a variable, and the square shape is reflected as an indicator. In this study, each variable is the same as the indicator, then also explained between direct and indirect relationships. The direct connection is inflation with the JCI, the exchange rate, the JCI, the SBI Interest Rate with the JCI, and the Dow Jones Index with the JCI.

The results of the Structural Model Evaluation with $\mathrm{R}$ Square show the following data:

Table 4 Significance Test

\begin{tabular}{|l|c|c|c|c|c|}
\hline & $\begin{array}{c}\text { Original Sample } \\
\text { (O) }\end{array}$ & Mean (M) & $\begin{array}{c}\text { Standard Deviation } \\
\text { (STDEV) }\end{array}$ & $\begin{array}{c}\text { T Statistic } \\
\text { (I O/STDEV I) }\end{array}$ & $\begin{array}{c}\text { P } \\
\text { Values }\end{array}$ \\
\hline JCI & 0.865 & 0.876 & 0.022 & 40.043 & 0.000 \\
\hline
\end{tabular}

Source: PLS Data Processing Results

On the basis of the data in Table 4, the R2 value for the JCI variable is 0.865 , or 86.5 percent, according to the test results. This may be interpreted as indicating that the inflation, exchange rate, SBI interest rate, and Dow Jones index variables can 
explain 86.5 percent of the variability of the Composite Stock Price Index variable. Other variables not included in this research model have an impact on the remaining 13.5 percent, according to the findings of this study.

To evaluate the causality link created in the model, specifically, the relationship between exogenous variables and the relationship between moderating factors and endogenous variables, hypothesis testing is utilized. T statistics, as seen in the accompanying table, provide information on hypothesis testing.

Table 5 Hypothesis Test (t-test)

\begin{tabular}{|l|c|c|c|c|c|}
\hline & $\begin{array}{c}\text { Original } \\
\text { Sample (O) }\end{array}$ & $\begin{array}{c}\text { Mean } \\
(\mathbf{M})\end{array}$ & $\begin{array}{c}\text { Standard Deviation } \\
\text { (STDEV) }\end{array}$ & $\begin{array}{c}\text { T Statistic } \\
(\mid \text { O/STDEV I) }\end{array}$ & $\begin{array}{c}\text { P } \\
\text { Values }\end{array}$ \\
\hline BI RATE -> JCI & -0.046 & -0.053 & 0.069 & 0.666 & 0.507 \\
\hline DJIA -> JCI & 0.982 & 0.983 & 0,059 & 16.543 & 0,000 \\
\hline INFLATION-> JCI & -0.172 & -0.162 & 0.079 & 2.189 & 0.032 \\
\hline EXCHANGE -> JCI & -0.317 & -0.310 & 0.062 & 5.112 & 0.000 \\
\hline
\end{tabular}

Source: PLS Data Processing Results

For example, if the T-Statistic value is larger than the critical value (t-table), it is suggested that an influence exists between the exogenous variables and their effects on their effects on the endogenous variables on each of the pre-defined hypotheses.

According to the first hypothesis, inflation has a negative and statistically significant impact on the JCI. Following the tests, the inflation variable has a Tstatistic value of 2.189 and a $p$-value of 0.032 , while the crucial value ( $t$ table) is 1.66 and has a p-value less than 0.05 or 5 percent. The results of the tests reveal: This results in a -0.172 on the original sample's results page. The results of the tests reveal that the T-statistical value is more than the critical value (t-table) and that the $\mathrm{p}$ value is less than 0.05 , indicating that the original model is negative.

It is proposed in the second hypothesis that the exchange rate has a negative and statistically significant impact on the JCI. The results of the tests reveal that the exchange rate variable has a T-statistical value of 5.112 and a p-value of 0.000 , whereas the critical value ( $t$ table) is 1.66 and the p-value is less than 0.05 or 5 percent, and the critical value ( $t$ table) is less than 0.05 or 5 percent. The findings of the original sample are -0.317 , as is the result of the second sample. The results of the test reveal that the T-statistical value is more than the critical value (t-table) and the p-value is less than 0.05 , indicating that the original sample is negative.

Lastly, the third hypothesis asserts that the SBI interest rate has little or a negative impact on the JCI. T-statistic values of 0.666 and 0.507 are obtained for the SBI Interest Rate variable, while the critical value ( $t$ table) is 1.66 and the p-value is less than 0.05 , or 5 percent, is obtained for the SBI Interest Rate variable. This results in a -0.046 in the original sample's results as well. The results of the test reveal that the value of T-statistics is greater than the critical value (t-table) and the p-value is greater than 0.05 , and the original sample is positive.

It is proposed in the fourth hypothesis that the Dow Jones Index has a positive and statistically significant impact on the JCI. These tests reveal that the 
exchange rate variable has a T-statistical value of 16.543 and a p-value of 0.000 , whereas the critical value ( $t$ table) is 1.66 and a p-value of less than 0.05 or 5 percent for the crucial variable ( $t$ table). In addition, the initial sample results are 0.982 percent. The results of the tests demonstrate that the T-statistical value is more than the critical value (t-table) and that the p-value is less than 0.05 , and therefore the original sample is positive.

\section{CONCLUSION}

According to the first hypothesis, inflation has a statistically significant negative impact on the JCI. This indicates that the higher the rate of inflation, the lower the value for the JCI. Specifically, the second hypothesis indicates that the exchange rate has a statistically significant negative impact on the JCI. According to this data, the direction of exchange rates is directly influenced by the variable. The higher the exchange rate is, the lower the JCI figure. Third, it is hypothesized that the SBI Interest Rate has no influence on the JCI and is even negative for the index. As a result, the rising number of SBI interest rates has no effect on the JCI, as previously stated. It is proposed in the fourth hypothesis that the Dow Jones Index has a statistically significant beneficial influence on the JCI. According to this, the rising Dow Jones index has an effect on the JCI.

\section{REFERENCES}

1. Astuti, R. (2016). Pengaruh Faktor Makro Ekonomi Terhadap Indeks Harga Saham Gabungan (IHSG) di Bursa Efek Indonesia (BEI) Periode 2006-2015. Jurnal Berkala Ilmiah Efisiensi, 16(2).

2. Bank Indonesia. (2012). Indonesia Financial Statistic. Jakarta: BI.

3. Bank Sentral Indonesia. (2019). Data BI Rate. Available at: http://www.bi.go.id/web/id/moneter/bi+rate/data+BI+rate.html, Retrieved on 15 January 2019.

4. Dwi Santi, R., \& Diena Hidayat, S. (2017). Pengaruh Rasio Pembayaran DPR dan Tingkat Suku Bunga BI Terhadap Harga Saham Perusahaan Manufaktur Sub Sektor Properti dan Real Estate pada Bursa Efek Indonesia BEI Periode 20052013. JIKA: Jurnal Ilmu Keuangan dan Perbankan, 3(2).

5. Febriyanto, F. (2016). Analisis Perubahan Nilai Indonesia Crude Price (ICP) Dan Pengaruhnya Terhadap Indeks Harga Saham Gabungan (IHSG) Periode Pengamatan Sebelum Pemberlakuan MEA. Derivatif: Jurnal Manajemen, 10(1).

6. Ilmi, M. F. (2017). Pengaruh Kurs/Nilai Tukar Rupiah, Inflasi dan Tingkat Suku Bunga SBI Terhadap Indeks Harga Saham Gabungan LQ-45 Periode Tahun 20092013. Nominal: Barometer Riset Akuntansi dan Manajemen, 6(1), 93-108.

7. Jogiyanto. (2000). Teori Portofolio dan Analisis Investasi Yogyakarta: BPFE.

8. Kewal, S. S. (2012). Pengaruh Inflasi, Suku Bunga, Kurs, dan Pertumbuhan PDB Terhadap Indeks Harga Saham Gabungan. Jurnal Economia, 8(1), 53-64.

9. Kuncoro, M. (2013). Metode Riset untukBisnis dan Ekonomi. Jakarta: Erlangga. 
10. Kurniawan, Y. J. (2013). Analisis Pengaruh Tingkat Suku Bunga SBI, Inflasi, Harga Minyak Dunia, Harga Emas Dunia, Kurs Rupiah terhadap Dollar Amerika, Indeks Nikkei 225, dan Indeks Dow Jones terhadap Indeks Harga Saham Gabungan. Jurnal Ilmiah.

11. Samsul, M. (2006). Pasar Modal dan Manajemen Portofolio. Jakarta: Erlangga.

12. Sari, W. I. (2019). Analisis Pengaruh Inflasi, Suku Bunga SBI, Nilai Tukar terhadap Return LQ 45 dan Dampaknya Terhadap Indeks Harga Saham Gabungan (IHSG) Di Bursa Efek Indonesia (BEI). Jurnal SEKURITAS (Saham, Ekonomi, Keuangan Dan Investasi), 3(1), 65-75.

13. Sukirno, S. (2010). Makroekonomi: Teori Pengantar. Volume III. Jakarta: Rajawali Pers

14. Sunariyah. (2003). Pengantar Pengetahuan Pasar Modal. Jakarta: Erlangga.

15. Syarofi, 2014. Analisis Pengaruh Suku Bunga SBI, Kurs Rupiah/US\$, Harga Minyak Dunia, Harga Emas Dunia, DJIA, Nikkei 225, dan Hang Seng Index Terhadap IHSG Dengan Metode GARCH-M (Periode Januari 2003-Mei 2013). Skripsi Universitas Diponegoro.

16. Tamara, S. F. (2013). Pengaruh Dow Jones Industrial Average, Deutscher Aktienindex, Shanghai Stock Exchange Composite Index, dan Straits Times Index Terhadap Indeks Harga Saham Gabungan di Bursa Efek Indonesia (Periode 20102012). Jurnal Ilmiah Mahasiswa FEB.

17. Taufiq, M., \& Kefi, B. S. (2015). Pengaruh Inflasi, BI Rate dan Kurs Terhadap Indeks Harga Saham Gabungan. Jurnal Ekonomi Manajemen Akuntansi, 22(38).

18. Thobarry, A. A. (2009). Analisis Pengaruh Nilai Tukar, Suku Bunga, Laju Inflasi dan Pertumbuhan GDP Terhadap Indeks Harga Saham Sektor Properti (Kajian Empiris pada Bursa Efek Indonesia Periode Pengamatan Tahun 2000-2008) (Doctoral Dissertation, Program Pasca Sarjana Universitas Diponegoro).

19. Wijaya, T. S. J., \& Agustin, S. (2015). Faktor-Faktor Yang Mempengaruhi Nilai IHSG yang Terdaftar di Bursa Efek Indonesia. Jurnal Ilmu dan Riset Manajemen (JIRM), 4(6).

20. Yanuar, A. Y. (2012). Dampak Variabel Internal dan Eksternal Terhadap Indeks Harga Saham Gabungan (IHSG) di Indonesia. Jurnal Ilmiah Mahasiswa FEB, 1(2). 